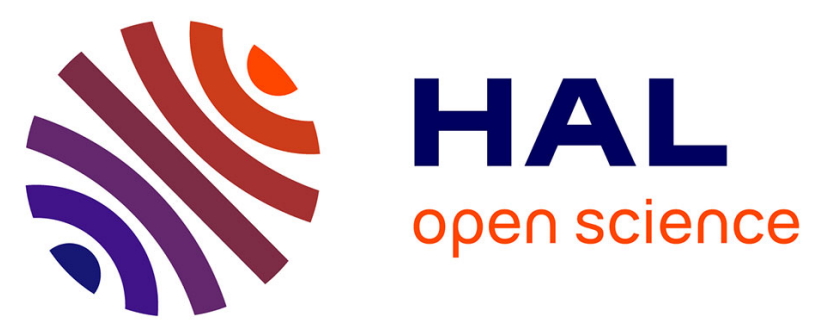

\title{
Synthesis of Mono- and Dihydroxylated Amino Acids with New $\alpha$-Ketoglutarate-Dependent Dioxygenases: Biocatalytic Oxidation of $\mathrm{C}-\mathrm{H}$ Bonds
}

Damien Baud, Pierre-Loïc Saaidi, Adam Monfleur, Marine Harari, Julien Cuccaro, Aurélie Fossey, Marielle Besnard, Adrien Debard, Aline Mariage, Virginie Pellouin, et al.

\section{To cite this version:}

Damien Baud, Pierre-Loïc Saaidi, Adam Monfleur, Marine Harari, Julien Cuccaro, et al.. Synthesis of Mono- and Dihydroxylated Amino Acids with New $\alpha$-Ketoglutarate-Dependent Dioxygenases: Biocatalytic Oxidation of C-H Bonds. ChemCatChem, 2014, 6, pp.3012 - 3017. 10.1002/cctc.201402498 . cea-01591870

\section{HAL Id: cea-01591870 https://hal-cea.archives-ouvertes.fr/cea-01591870}

Submitted on 22 Sep 2017

HAL is a multi-disciplinary open access archive for the deposit and dissemination of scientific research documents, whether they are published or not. The documents may come from teaching and research institutions in France or abroad, or from public or private research centers.
L'archive ouverte pluridisciplinaire HAL, est destinée au dépôt et à la diffusion de documents scientifiques de niveau recherche, publiés ou non, émanant des établissements d'enseignement et de recherche français ou étrangers, des laboratoires publics ou privés. 


\title{
Synthesis of Mono- and Dihydroxylated Amino Acids with New $\alpha$-Ketoglutarate-Dependent Dioxygenases: Biocatalytic Oxidation of $\mathrm{C}-\mathrm{H}$ Bonds
}

\author{
Damien Baud, Pierre-Loï Saaidi, Adam Monfleur, Marine Harari, Julien Cuccaro, \\ Aurélie Fossey, Marielle Besnard, Adrien Debard, Aline Mariage, Virginie Pellouin, \\ Jean-Louis Petit, Marcel Salanoubat, Jean Weissenbach, Véronique de Berardinis, and \\ Anne Zaparucha*[a]
}

Iron(II)/ $\alpha$-ketoacid-dependent oxygenases (aKAOs) are en-
zymes that mainly catalyse hydroxylation reaction. By using
a genomic approach combining sequence comparison and
protein-domain sharing, a set of 131 aKAO enzymes was pre-
pared. The screening of various substrates revealed five new
$\alpha K A O s$. Four $\alpha$ KAOs were found to be active towards L-lysine,

\section{Introduction}

The insertion of an oxygen atom into an unactivated $\mathrm{C}-\mathrm{H}$ bond is commonly used by nature in biosynthetic pathways; however, it remains a tremendous challenge for chemists. ${ }^{[1]}$ For a long time, cytochrome P450 monooxygenases have attracted attention owing to exceptional oxidative capacities and broad substrate scope as a result of their biological roles. ${ }^{[2]}$ Over the past decade, an increasing number of publications have revealed the diversity of another oxygenase superfamily-the iron(II)/ $\alpha$-ketoacid-dependent oxygenases (aKAOs). ${ }^{[3]}$ Concomitant to the oxidation of the substrate by molecular oxygen, most frequently hydroxylation, these enzymes mediate the oxidative decarboxylation of $\alpha$-ketoglutarate $(\alpha K G)$ to succinate without the need of any additional cofactor or regenerating enzymatic systems.

$\alpha \mathrm{KAOs}$ are involved in various biological processes, for example DNA demethylation, collagen post-translational modifi-

[a] Dr. D. Baud, ${ }^{+}$Dr. P.-L. Saaidi, A. Monfleur, M. Harari, J. Cuccaro, A. Fossey, M. Besnard, A. Debard, A. Mariage, V. Pellouin, J.-L. Petit, Dr. M. Salanoubat, Dr. J. Weissenbach, Dr. V. de Berardinis, Prof. A. Zaparucha CEA, DSV, IG, Genoscope

CNRS-UMR8030

2 rue Gaston Crémieux

91057 Evry (France)

and

Université Evry Val d'Essonne

Boulevard François Mitterrand

91000 Evry (France)

E-mail: azaparuc@genoscope.cns.fr

$\left.{ }^{+}\right]$Current address:

Department of Chemistry, University College of London

20 Gordon Street

London WC1H OAJ (UK)

Supporting information for this article is available on the WWW under http://dx.doi.org/10.1002/cctc.201402498.
L-ornithine and L-arginine with total regio- and stereoselectivities and yielding the corresponding 3- or 4-hydroxyamino acids. The enzymatic cascade reaction with two stereoselective regiodivergent $\alpha \mathrm{KAO}$ s enabled the synthesis of 3,4-dihydroxyL-lysine. cations, or oxidation steps in secondary metabolite biosynthesis. ${ }^{[3 e-i, k, s, 4]}$ Several bacterial $\alpha$ KAOs have been reported to hydroxylate the side chain of free amino acids or tethered peptides in non-ribosomal peptide biosynthesis. Hydroxylated amino acids contain several stereogenic centres and are thus valuable chiral building blocks for fine chemical synthesis. However, except for the production of hydroxyprolines, which found applications in pharmaceutical and feed industries, with L-proline hydroxylases, the use of $\alpha$ KAOs in industrial biocatalytic processes is infrequent. ${ }^{[5]}$ We herein report the discovery of new dioxygenases active towards free amino acids and related compounds by using a genome-mining approach.

\section{Results and Discussion}

Putative $\alpha$ KAOs were selected in a two-step process. Firstly, we selected 274 proteins having sequence identity greater than $30 \%$ with a set of experimentally validated aKAOs. Then, we added 56 enzymes depending on the presence of the InterPro motif of proline hydroxylases (IPR007803) or MppO/VioC/AsnO enzymes (IPR014503) catalysing the hydroxylation of amino acids and derivatives in non-ribosomal peptide biosynthesis (Tables S1 and S2. ${ }^{[3 e-h]}$ This step led to a collection of 331 candidate $\alpha K A O s$, including a putative dioxygenase from our model organism Acinetobacter baylyi ADP1. ${ }^{[6]}$ Finally, 131 candidate aKAOs were cloned in an expression vector and heterologously expressed in Escherichia coli strain BL21 with a histidine tag.

The panel of tested substrates was organised into 12 pools (Figure 1), which included known substrates, known substrate derivatives, L-amino acids (pools 1-4, 6, and 10-12), together with amine and keto derivatives for which stereoselective hydroxylation could be performed to produce valuable chiral 

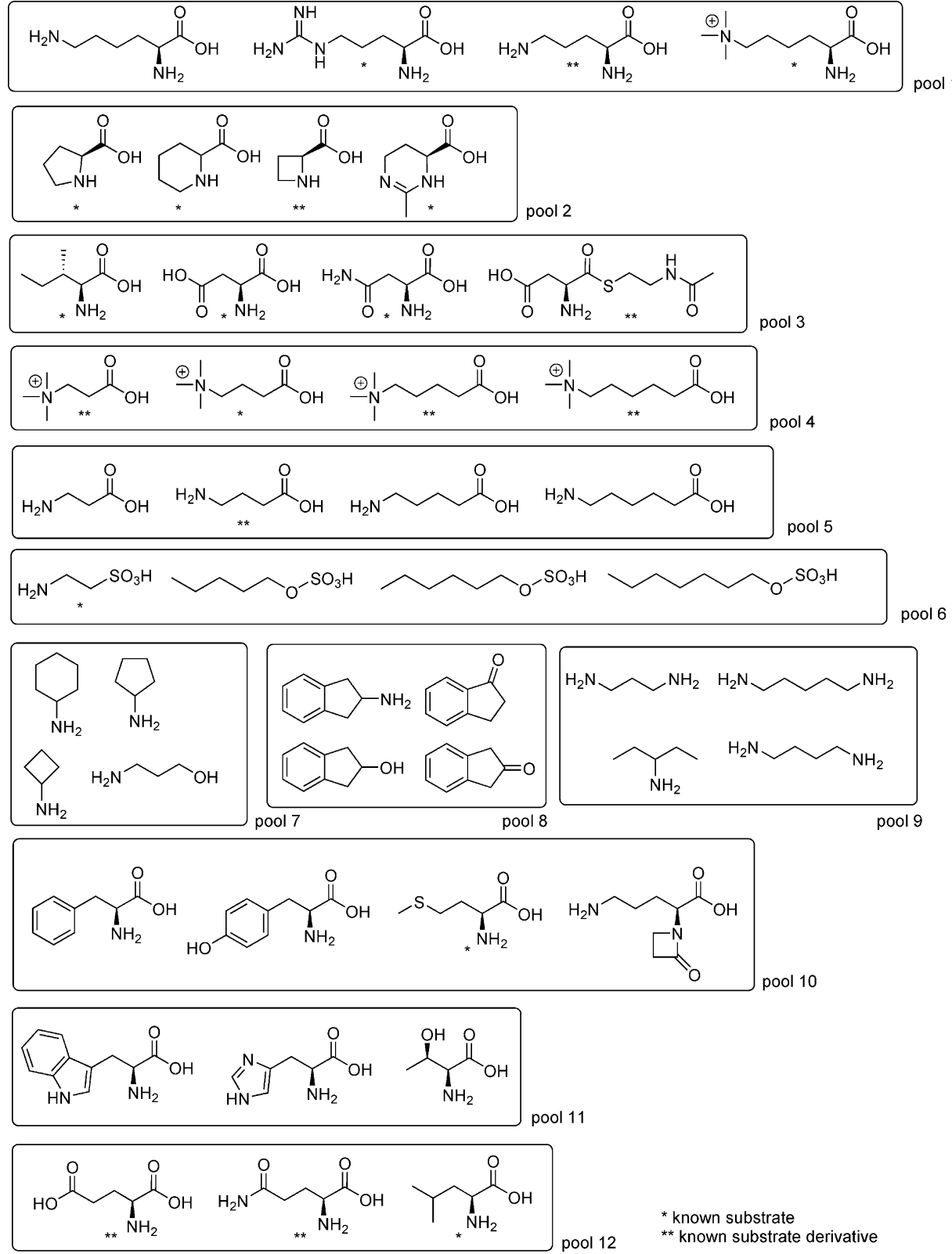

Figure 1. Pool of substrates.

scaffolds (pools 5 and 7-9). The 131 candidate $\alpha$ KAOs were screened as cell-free extracts against the 12 pools in 96-microwell plates. The dioxygenase activity assay was based on the spectrophotochemical titration of $\alpha \mathrm{KG}$ with glutamate dehydrogenase. ${ }^{[7]}$ The proteins demonstrating a significant activity on at least one pool of substrates were purified and studied on individual substrates by using HPLC or GC-MS. Five enzymes demonstrated dioxygenase activity on at least one of the following substrates: hexyl sulphate, lysine, ornithine and arginine. Enzymes catalysing oxidations of arginine and hexyl sulphate with aKAOs have already been described; however, these enzymes are not phylogenetically closely related to those discovered in our screening (Table 1). ${ }^{[3, f, 8]}$ We found three L-lysine dioxygenases, namely $\mathrm{KDO} 1-3$, as well as one
* known substrate ${ }^{* *}$ known substrate derivative

L-ornithine dioxygenase, also active on L-arginine, namely ODO. KDO1 and ODO share low sequence identity with known aKAOs active towards amino acids and derivatives (VioC, MppO and AsnO; Table 1). Both $\mathrm{KDO} 2$ and KDO3 that share $63 \%$ of sequence identity were detected by the InterPro domain search (IPR014503), and no overall identity was found with already known $\alpha$ KAOs.

Because neither lysine nor ornithine was reported as an aKAO substrate, we decided to focus our studies on the four $\alpha K A O s$. The enzymatic reactions proceeded with total regio- and stereoselectivities because only one compound was detected by using HPLC after chiral derivatisation with Marfey's reagent. Under the optimal reaction conditions, a complete conversion of L-lysine was observed for KDO1-3 whereas ODO led to 68 and $50 \%$ conversion of L-ornithine and L-arginine derivatives, respectively (see the Supporting Information for details). The specific activities were determined with L-lysine for KDO1-3 and with L-ornithine for ODO: $1.448 \mu \mathrm{mol} \mathrm{min}^{-1} \mathrm{mg}^{-1}$ for KDO1; $1.60 \mu \mathrm{mol} \mathrm{min}^{-1} \mathrm{mg}^{-1}$ for $\mathrm{KDO} 2$; $1.419 \mu \mathrm{mol} \mathrm{min}^{-1} \mathrm{mg}^{-1}$ for KDO3; and $0.13 \times 10^{-3} \mu \mathrm{mol} \mathrm{min}{ }^{-1} \mathrm{mg}^{-1}$ for ODO.

To elucidate the product structures, we then performed the enzymatic reactions on a preparative scale. The direct extraction of the hydroxylated amino acids from the reaction media remained unsatisfactory, and a two-step method with tert-butoxycarbonyl (Boc) derivatisation was used (Scheme 1; also see the Supporting Information for details). KDO1 led to the formation of (3S)-3-hydroxy-L-lysine as determined by using the Mosher method. ${ }^{[9]}$ Both $\mathrm{KDO} 2$ and $\mathrm{KDO} 3$ products tended to cyclise into $\gamma$-lactone during the two-step isolation method, which indicated a $\mathrm{C} 4$ regioselective hydroxylation. ${ }^{[10]}$ The $\mathrm{H} 2-$ $\mathrm{H} 4$ protons of $\gamma$-lactone appeared to have a cis relationship, which indicated the formation of (4R)-4-hydroxy-L-lysine in the enzymatic step (see the Supporting Information for details). ${ }^{[1]}$ Concerning the regioselective hydroxylation of amino acids and derivatives with $\alpha \mathrm{KAOs}$, the $\mathrm{C} 3$ regioselectivity is observed much more frequently than the $\mathrm{C} 4$ regioselectivity. $\mathrm{C} 4$ regiose- 


\begin{tabular}{|c|c|c|c|c|c|}
\hline Enzyme & $\begin{array}{l}\text { UniProtKB } \\
\text { ID }\end{array}$ & Annotation & Organism & $\begin{array}{l}\text { Closest sequence } \\
\text { identity }\end{array}$ & Substrate \\
\hline KDO1 & C7QJ42 & $\begin{array}{l}\text { uncharacterised } \\
\text { protein }\end{array}$ & $\begin{array}{l}\text { Catenulispora } \\
\text { acidiphila } \\
\text { (DSM 44928) }\end{array}$ & $32 \%{ }^{[a]}$ & L-lysine \\
\hline KDO2 & C7PLM6 & $\begin{array}{l}\text { uncharacterised } \\
\text { protein }\end{array}$ & $\begin{array}{l}\text { Chitinophaga } \\
\text { pinensis } \\
\text { (DSM 2588) }\end{array}$ & $<30 \%^{[\mathrm{b}]}$ & L-lysine \\
\hline KDO3 & A5FF23 & $\begin{array}{l}\text { uncharacterised } \\
\text { protein }\end{array}$ & $\begin{array}{l}\text { Flavobacterium } \\
\text { johnsoniae } \\
\text { (DSM 2064) }\end{array}$ & $<30 \%^{[b]}$ & L-lysine \\
\hline ODO & C7Q942 & $\begin{array}{l}\text { uncharacterised } \\
\text { protein }\end{array}$ & $\begin{array}{l}\text { Catenulispora } \\
\text { acidiphila } \\
\text { (DSM 44928) }\end{array}$ & $44 \%{ }^{[a]}$ & $\begin{array}{l}\text { L-orni- } \\
\text { thine } \\
\text { L-argi- } \\
\text { nine }\end{array}$ \\
\hline AtsK & Q6FBW1 & alkylsulphatase & $\begin{array}{l}\text { Acinetobacter } \\
\text { baylyi } \\
\text { ADP1 }\end{array}$ & $61 \%{ }^{[c]}$ & $\begin{array}{l}\text { hexyl } \\
\text { sulphate }\end{array}$ \\
\hline
\end{tabular}

[a] With VioC (Q6WZBO) from Streptomyces vinaceus;; $;$, [3, [b] C7PLM6 and A5FF23 shared $63 \%$ of sequence identity; [c] With AtsK (Q9WWU5) from Pseudomonas putida. ${ }^{[8 \mathrm{a}]}$
Although new aKAOs are active towards similar substrates, they are not homologous with each other, except for $\mathrm{KDO} 2$ and $\mathrm{KDO} 3$, which perform the same reaction and share $63 \%$ of sequence identity (Table 1). A recent update of our sequence survey revealed the deposit of two homologues of KDO2 and $\mathrm{KDO} 3$ in the UniProt Knowledgebase (UniProtKB). Experimental studies revealed their $C 4$ regioselectivity on L-lysine, and the two sequences were, respectively, named KDO4 (G2T8D0) and KDO5 (J3BZS6) (see the Supporting Information for details). However, no sequence similar to that of KDO1 was retrieved.

To investigate their substrate tolerances, KDO1-3 and ODO were screened against D-amino acids and substrate derivatives demonstrating various functional modifications: protection by a methyl ester of $\alpha$ carboxylic acid, protection by an acetyl group on the $\alpha$-amine, substitution of the $N$ - $\varepsilon$-amine, carboxylic acid in place of the $N$ - $\varepsilon$-amine, suppression of the $N$ $\varepsilon$-amine, cyclisation, dimerisation and incorporation of a sulphur atom into the lateral chain. We evaluated the activity on (3S)- and (4R)hydroxyl-L-lysines (synthesised enzymatically in situ) as well as on (5R)-5-hydroxy-L-lysine; these monohydroxylated L-lysines were precursors of dihydroxy-Llysines, which were, in turn, highly functionalised chiral scaffolds (Table S3).

For the four $\alpha K A O s$, the substrate scope was narrow because only closely related amino acid derivatives were found as substrates (Table 2). None of the tested compounds was the substrate of ODO. The three KDOs were active towards 3-, 4- and 5hydroxy-L-lysines, which gave access to different dihydroxy- $L-$ lysines. Notably, 3,4-dihydroxy-Llysine was obtained through the
Scheme 1. Biocatalytic synthesis of hydroxylated amino acids. (i) $\alpha \mathrm{KAO}$, substrate $(0.1 \mathrm{mmol}), \alpha \mathrm{KG}$ (1.5 equiv.), ascorbate (0.25 equiv.; except for ODO: none), Mohr's salt $(0.1 \mathrm{mmol})$, HEPES ( $50 \mathrm{~mm}, \mathrm{pH} 7.5)$, room temperature, $18 \mathrm{~h}, 300 \mathrm{rpm}$. (ii) $\mathrm{Boc}_{2} \mathrm{O}$ (2 equiv.), $5 \% \mathrm{NaOH} / \mathrm{EtOH}(1: 1)$, room temperature, 4 h. $2: 73 \%$ isolated yield; $4: 75 \%$ isolated yield; $6: 42 \%$ isolated yield. (iii) $\mathrm{HCl}(4 \mathrm{M})$ in dioxane solution, room temperature, $1 \mathrm{~h} .1 \cdot 2 \mathrm{HCl}$ : quantitative yield; $3 \cdot 2 \mathrm{HCl}$ : quantitative yield; $5 \cdot 2 \mathrm{HCl}$ : quantitative yield. lective hydroxylation has been reported for aliphatic amino acids and proline, whereas an $\alpha \mathrm{KAO}$ dihydroxylase catalysing the conversion of L-arginine into $(3 R, 4 R)$-3,4-dihydroxy-L-arginine was recently discovered in the streptolidine gene cluster from Streptomyces species; thus, KDO2 and KDO3 are the first C4 regioselective $\alpha$ KAOs that are active towards a polar amino acid such as L-lysine. ${ }^{[3 \mathrm{~m}, \mathrm{~s}, \mathrm{t}, 5 \mathrm{e}]}$ ODO catalyses the C3 regioselective and (S)-stereoselective hydroxylation of both L-ornithine and L-arginine, as demonstrated by the comparison of NMR data of synthetic products (Scheme 1; also see the Supporting Information for details). ${ }^{[12]}$ Notably, ODO catalyses the hydroxylation of L-arginine with the same regio- and stereoselectivities as of VioC, an $\alpha \mathrm{KAO}$ involved in the biosynthesis of viomycin, which is an antibiotic produced by Streptomyces species. ${ }^{[3 e]}$

\begin{tabular}{|c|c|c|c|c|}
\hline Substrate & KDO1 & KDO2 & KDO3 & ODO \\
\hline thialysine $e^{[a]}$ & - & + & + & - \\
\hline (3S)-3-hydroxy-L-lysine $e^{[b]}$ & & + & + & - \\
\hline (4R)-4-hydroxy-L-lysine $\mathrm{e}^{[\mathrm{b}]}$ & + & & & - \\
\hline (5R)-5-hydroxy-L-lysine & + & + & + & - \\
\hline
\end{tabular}

[a] Aminoethyl-L-cysteine; [b] Synthesised enzymatically in situ.

cascade reaction with $\mathrm{KDO} 1$ and $\mathrm{KDO}$. The reaction was performed on a preparative scale, which yielded $53 \%$ of $(3 R, 4 R)$ 3,4-dihydroxy-L-lysine as $\gamma$-lactone (Scheme 2). 


$$
\stackrel{\text { (iii) }}{\longrightarrow} \text { (i) }
$$

Scheme 2. Biocatalytic cascade synthesis of (3R,4R)-3,4-dihydroxy-L-lysine. (i) KDO1 $(1.3 \mathrm{mg})$, L-lysine $(0.1 \mathrm{mmol})$, $\alpha$ KG (1.5 equiv.), ascorbate ( 0.25 equiv.), Mohr's salt ( 0.1 equiv.), HEPES $(50 \mathrm{~mm}, \mathrm{pH} 7.5)$, room temperature, $18 \mathrm{~h}$, $300 \mathrm{rpm}$. (ii) $\mathrm{KDO} 3$ (4.24 mg). (iii) $\mathrm{Boc}_{2} \mathrm{O}$ (2 equiv.), $5 \% \mathrm{NaOH} / \mathrm{EtOH}$ (1:1), room temperature, $4 \mathrm{~h} ; 53 \%$ isolated yield from L-lysine. (iv) Dichloromethane, room temperature, overnight. (v) $\mathrm{HCl}(4 \mathrm{M})$ in dioxane solution, room temperature, $1 \mathrm{~h}$; quantitative yield.

\section{Conclusions}

Our genome-mining approach led to the discovery of four new $\alpha$-ketoacid-dependent oxygenases hydroxylating the side chains of basic amino acids. Two of them, KDO2 and KDO3 (i.e., L-lysine dioxygenases), demonstrated a $\mathrm{C} 4$ regioselectivity rather than the $\mathrm{C} 3$ regioselectivity frequently encountered for the hydroxylation of amino acids and derivatives. To investigate the C3/C4 regioselectivity of the hydroxylation reaction of amino acids, structural studies combining X-ray crystallography, homology modelling and directed mutagenesis are underway.

Despite a limited substrate range, the new enzymes are of interest for biocatalytic purposes because they proved to be totally regio- and stereoselective. A highly efficient enzymatic synthesis of hydroxy-L-ornithine and mono- and dihydroxy-Llysine was performed with new $\alpha$-ketoacid-dependent oxygenases. ${ }^{[13]}$ These chiral scaffolds are of synthetic value in the preparation of more complex functionalised chiral molecules such as natural products and analogues.

\section{Experimental Section}

\section{Selection of candidate enzymes}

A set of $11 \alpha K A O s$ related to published experimental data was prepared. This set was used for protein-versus-protein alignments with the BL2 option (BLAST allowing gaps) and a BLOSUM62 scoring matrix against the UniProtKB. Identities restricted to those presenting more than $30 \%$ identity over at least $80 \%$ of the length of the smaller of two compared sequences were retained (579 proteins). Then, all members (461 proteins) of the InterPro motif of proline hydroxylases (IPR007803) and MppO/VioC/AsnO enzymes (IPR014503) were added to the set. To minimise the number of candidates, protein sequences were clustered ( $80 \%$ of identity) as described previously. ${ }^{[14]}$

\section{Cloning, candidate enzyme production and enzyme purifica- tions}

All steps were performed in 96-microwell plates. Primers were chosen by using the Primer3 program. ${ }^{[15]}$ Oligonucleotides were obtained from Sigma-Genosys (St Quentin Fallavier, France). Specific extensions were added to the primers for cloning into the plasmid pET-22b(+) (Novagen, VWR, Fontenay-sous-Bois, France) modi- fied for ligation-independent cloning. ${ }^{[16]}$ The forward primers introduced a hexahistidine sequence in the proteins after the initial methionine for purification purposes. Plasmids were then introduced into $E$. coli $\mathrm{BL} 21(\mathrm{DE} 3)$ plysE strains (Invitrogen, Life technologies SAS, Saint Aubin, France) for overexpression. KDO4 and KDO5 genes optimised for synthetic gene expression in $E$. coli were purchased from Genwiz (Sigma Aldrich, Saint Quentin Fallavier, France) and recloned into the modified $\mathrm{pET}$ $22(+)$ with a histidine tag. Cell cultures, isopropyl $\beta$-D-thiogalactopyranoside induction for protein production, and cell extraction were performed as reported previously. ${ }^{[b]}$ For the production of the enzymes used for the initial screening, an adaptation to 96-microwell plate conditions was needed. Briefly, a cell culture $(1.6 \mathrm{~mL})$ was induced for recombinant protein production in each well. After centrifugation, cells were suspended in potassium phosphate buffer $(300 \mu \mathrm{L}, 50 \mathrm{~mm}, \mathrm{pH} 7.3)$ containing $\mathrm{NaCl}(50 \mathrm{~mm}), 10 \%$ glycerol, Pefabloc SC (Sigma-Aldrich, Saint Quentin Fallavier, France) (1 $\mathrm{mm})$, and Lysonase bioprocessing reagent $(0.2 \mu \mathrm{L}$; Merck) and then sonicated in an ultrasonic bath (Branson Ultrasonic Cleaner). After centrifugation to clarify the cell extract, the supernatants were analysed by using sodium dodecyl sulphate polyacrylamide gel electrophoresis to check for recombinant protein production. Protein concentrations were determined by using the Bradford method with bovine serum albumin as the standard (Bio-Rad). The samples were stored at $-80^{\circ} \mathrm{C}$.

The enzymes were purified by loading the crude extract onto a $\mathrm{Ni}$ NTA column (Qiagen, Courtaboeuf, France) according to the manufacturer's instructions. Large-scale purifications were performed by using nickel affinity purifications, as reported previously. ${ }^{[\mathrm{b}]}$ Protein concentrations were determined by using the Bradford method. The samples were analysed by using sodium dodecyl sulphate polyacrylamide gel electrophoresis with the Invitrogen NuPAGE electrophoresis system. The purified proteins were stored at $-80^{\circ} \mathrm{C}$.

\section{High-throughput enzymatic assay}

All the reactions were performed in 96-microwell plates. The enzymatic reactions were performed with a mixture of $\alpha \mathrm{KG}(220 \mu \mathrm{L}$, $1 \mathrm{~mm})$, sodium ascorbate $(2.5 \mathrm{~mm})$, Mohr's salt $(1 \mathrm{~mm})$, cell lysate (from 0.04 to $0.54 \mu \mathrm{g} \mathrm{L}^{-1}$ of protein), substrate $(5 \mathrm{~mm})$ in $\mathrm{N}$-(2-hydroxyethyl)piperazine- $N$-ethanesulfonic acid (HEPES) buffer $(50 \mathrm{~mm}, \mathrm{pH} 7.5)$ at RT for $18 \mathrm{~h}$. Each well $(90 \mu \mathrm{L})$ was transferred to a $96-$ microwell daughter plate. Then, a mixture $(130 \mu \mathrm{L})$ containing $\mathrm{NADH}(600 \mu \mathrm{M}), \mathrm{NH}_{4} \mathrm{Cl}(50 \mathrm{~mm})$, glutamate dehydrogenase $\left(18.18 \mu \mathrm{g} \mathrm{mL}^{-1}\right)$ in tris(hydroxymethy1)aminomethane (TRIS) buffer $(50 \mathrm{~mm}, \mathrm{pH} 7.5)$ was added. The oxidation of NADH was monitored to evaluate the remaining $\alpha \mathrm{KG} .{ }^{[7]}$

\section{General method for hydroxylation with an $\alpha$ KAO enzyme}

The enzymatic reaction was performed in $250 \mathrm{~mL}$ glass Erlenmeyer flask with a total volume of $4 \times 10 \mathrm{~mL}$. Water $(4.8 \mathrm{~mL})$, HEPES buffer $(\mathrm{pH} 7.50,50 \mathrm{~mm})$, L-lysine $(10 \mathrm{~mm}), \alpha \mathrm{KG}(15 \mathrm{~mm})$, sodium ascorbate $(2.5 \mathrm{~mm})$, ammonium iron(II) sulphate hexahydrate $(1 \mathrm{~mm})$ 
were poured into the Erlenmeyer flask. The reaction was started by the addition of an enzyme (final concentration: $0.024 \mathrm{mg} \mathrm{mL}^{-1}$ ). The reaction mixture was orbitally shaken (300 rpm) at RT for $18 \mathrm{~h}$. The conversion (94\%) was determined from HPLC analysis after derivatisation with fluorenylmethyloxycarbonyl chloride (see the Supporting Information for details).

The assembled reaction mixtures were first acidified with trifluoroacetic acid $(200 \mu \mathrm{L})$ and then centrifuged. The supernatant was collected and freeze dried. The crude product was diluted in minimum water and eluted through a cation-exchange resin (Dowex $50 \mathrm{WX} 8-200)$ with a $\mathrm{pH}$ gradient from $\mathrm{HCl}(0.1 \mathrm{M})$ to $3.5 \% \mathrm{NH}_{3}$ in water solution. The fractions containing the product were assembled, and the solvent was evaporated under reduced pressure to obtain crude hydroxy amino acid.

\section{General method for derivatisation with the tert-butoxycar- bonyl group on the hydroxy amino acid}

The hydroxy amino acid (1 equiv.) was solubilised in $10 \% \mathrm{NaOH}$ in water solution $(400 \mu \mathrm{L}, 0.8 \mathrm{mmol}, 2$ equiv.), and the solution was cooled to $0^{\circ} \mathrm{C}$. Di-tert-butyl dicarbonate $\left(\mathrm{Boc}_{2} \mathrm{O} ; 4 \mathrm{M}\right)$ in ethanol ( $400 \mu \mathrm{L}, 1.6 \mathrm{mmol}, 4$ equiv.) was added dropwise to the solution, and the resulting mixture was stirred at RT for $4 \mathrm{~h}$. Water $(3 \mathrm{~mL})$ was added, and the aqueous layer was extracted with petroleum ether $(3 \times 3 \mathrm{~mL})$ to eliminate the excess of $\mathrm{Boc}_{2} \mathrm{O}$. The aqueous layer was acidified with $\mathrm{HCl}(1 \mathrm{M})$ until $\mathrm{pH} 2$ and extracted with ethyl acetate $(3 \times 3 \mathrm{~mL})$. The assembled organic layers were dried over anhydrous $\mathrm{MgSO}_{4}$, filtered, and evaporated to obtain yellow oil. Purification by using flash chromatography with the gradient mixture of $85-35 \%$ hexane $+0.3 \% \mathrm{HCO}_{2} \mathrm{H} / \mathrm{AcOEt}+0.3 \% \mathrm{HCO}_{2} \mathrm{H}$ in $20 \mathrm{~min}$ afforded the diBoc-hydroxy amino acid.

\section{General method for the cleavage of tert-butoxycarbonyl groups on the diBoc-hydroxy amino acid}

The diBoc-hydroxy amino acid (1 equiv.) was solubilised in $\mathrm{HCl}$ $(4 \mathrm{M})$ in dioxane solution ( $345 \mu \mathrm{L}, 1.38 \mathrm{mmol}, 11.5$ equiv.), and the reaction mixture was stirred at RT for $1 \mathrm{~h}$. The solvent was removed under reduced pressure, and the residue was triturated successively in toluene $(3 \times 1 \mathrm{~mL})$, diethyl ether $(3 \times 1 \mathrm{~mL})$, dichloromethane $(3 \times 1 \mathrm{~mL})$ and dried under vacuum overnight, which afforded the hydroxy amino acid dihydrochloride as a white solid.

\section{Acknowledgements}

This work was supported by a Ph.D. studentship (to D.B.) from the Université Evry Val d'Essonne. We gratefully acknowledge Dr. Tsung-Lin Hi (Genomics Research Center, Academia Sinica, Taipei, Taiwan) for sending $R X$ and sequence data before public release. We also thank Lucille Stuani for MS analyses; Olivier Péruch for excellent technical assistance; and Dr. Carine Vaxelaire, Dr. Alain Perret, and Dr. Volker Döring for helpful discussions.

Keywords: amino acids • biocatalysis - dioxygenase
hydroxylation $\cdot$ regioselectivity

[1] a) O. Baudoin, Chem. Soc. Rev. 2011, 40, 4902-4911; b) G. Dyker, Handbook of $\mathrm{C}-\mathrm{H}$ Transformations: Applications in Organic Synthesis, Wiley VCH, Weinheim, 2008; c) T. Newhouse, P. S. Baran, Angew. Chem. 2011, 123, 3422-3435; Angew. Chem. Int. Ed. 2011, 50, 3362-3374; d) J. Yama- guchi, A. D. Yamaguchi, K. Itami, Angew. Chem. 2012, 124, 9092-9142; Angew. Chem. Int. Ed. 2012, 51, 8960-9009; e) R. V. Ottenbacher, D. G. Samsonenko, E. P. Talsi, K. P. Bryliakov, Org. Lett. 2012, 14, 4310-4313; f) C. J. Shaffer, D. Schroder, C. Gutz, A. Lutzen, Angew. Chem. 2012, 124, 8221-8224; Angew. Chem. Int. Ed. 2012, 51, 8097-8100.

[2] a) R. Fasan, ACS Catal. 2012, 2, 647-666; b) M. K. Julsing, S. Cornelissen, B. Buhler, A. Schmid, Curr. Opin. Chem. Biol. 2008, 12, 177-186; c) K. Zhang, B. M. Shafer, M. D. Demars II, H. A. Stern, R. Fasan, J. Am. Chem. Soc. 2012, 134, 18695-18704.

[3] a) S. P. Salowe, E. N. Marsh, C. A. Townsend, Biochemistry 1990, 29, 6499-6508; b) H. Mori, T. Shibasaki, K. Yano, A. Ozaki, J. Bacteriol. 1997, 179, 5677-5683; c) T. Shibasaki, W. Sakurai, A. Hasegawa, Y. Uosaki, H. Mori, M. Yoshida, A. Ozaki, Tetrahedron Lett. 1999, 40, 5227-5230 d) R. P. Hausinger, Crit. Rev. Biochem. Mol. Biol. 2004, 39, 21-68; e) X. Yin, T. M. Zabriskie, ChemBioChem 2004, 5, 1274-1277; f) J. Ju, S. G. Ozanick, B. Shen, M. G. Thomas, ChemBioChem 2004, 5, 1281-1285; g) B. Haltli, Y. Tan, N. A. Magarvey, M. Wagenaar, X. Yin, M. Greenstein, J. A. Hucul, T. M. Zabriskie, Chem. Biol. 2005, 12, 1163-1168; h) M. Strieker, F. Kopp, C. Mahlert, L.-O. Essen, M. A. Marahiel, ACS Chem. Biol. 2007, 2, 187-196; i) G. M. Singh, P. D. Fortin, A. Koglin, C. T. Walsh, Biochemistry 2008, 47, 11310-11320; j) T. Kodera, S. V. Smirnov, N. N. Samsonova, Y. I. Kozlov, R. Koyama, M. Hibi, J. Ogawa, K. Yokozeki, S. Shimizu, Biochem. Biophys. Res. Commun. 2009, 390, 506-510; k) V. Helmetag, S. A. Samel, M. G. Thomas, M. A. Marahiel, L. O. Essen, FEBS J. 2009, 276, 36693682 ; I) R. Hara, K. Kino, Biochem. Biophys. Res. Commun. 2009, 379, 882-886; m) C. Klein, W. Hüttel, Adv. Synth. Catal. 2011, 353, 13751383; n) C. Klein, W. Hüttel, Beilstein J. Org. Chem. 2011, 7, 1643-1647; o) S. V. Smirnov, P. M. Sokolov, T. Kodera, M. Sugiyama, M. Hibi, S. Shimizu, K. Yokozeki, J. Ogawa, FEMS Microbiol. Lett. 2012, 331, 97-104; p) M. Hibi, T. Kawashima, T. Kasahara, P. M. Sokolov, S. V. Smirnov, T. Kodera, M. Sugiyama, S. Shimizu, K. Yokozeki, J. Ogawa, Lett. Appl. Microbiol. 2012, 55, 414-419; q) M. Hibi, T. Kawashima, P. Sokolov, S. Smirnov, T. Kodera, M. Sugiyama, S. Shimizu, K. Yokozeki, J. Ogawa, Appl. Microbiol. Biotechnol. 2013, 97, 2467-2472; r) S. V. Smirnov, P. M. Sokolov, V. A. Kotlyarova, N. N. Samsonova, T. Kodera, M. Sugiyama, T. Torii, M. Hibi, S. Shimizu, K. Yokozeki, J. Ogawa, MicrobiologyOpen 2013, 2, 471-481; s) C. Y. Chang, S. Y. Lyu, Y. C. Liu, N. S. Hsu, C. C. Wu, C. F. Tang, K. H. Lin, J. Y. Ho, C. J. Wu, M. D. Tsai, T. L. Li, Angew. Chem. Int. Ed. 2014, 53, $1943-1948$; t) M. Hibi, J. Ogawa, Appl. Microbiol. Biotechnol. 2014, 98, $3869-3876$.

[4] A. G. Prescott, M. D. Lloyd, Nat. Prod. Rep. 2000, 17, 367-383.

[5] a) A. Ozaki, H. Mori, T. Shibasaki, K. Ando, S. Chiba, US 2004/0048345 A1, 2004; b) K. Kino, R. Hara, US 2013/0330786 A1, 2013; c) H. Chen, K. O. Y. Bong Yong, F. Cabirol, A. Gohel, T. A. O. Li, C. Moore Jeffrey, M. Quintanar-Audelo, H. Yang, J. Collier Steven, D. Smith, WO 2013/169725 A2; d) R. M. Johnston, L. N. Chu, M. Liu, S. L. Goldberg, A. Goswami, R. N. Patel, Enzyme Microb. Technol. 2009, 45, 484-490; e) T. Shibasaki, H. Mori, A. Ozaki, Biosci. Biotechnol. Biochem. 2000, 64, 746-750.

[6] V. Barbe, D. Vallenet, N. Fonknechten, A. Kreimeyer, S. Oztas, L. Labarre, S. Cruveiller, C. Robert, S. Duprat, P. Wincker, L. N. Ornston, J. Weissenbach, P. Marliere, G. N. Cohen, C. Medigue, Nucleic Acids Res. 2004, 32, $5766-5779$.

[7] a) R. E. Rhoads, S. Udenfriend, Proc. Natl. Acad. Sci. USA 1968, 60, $1473-$ 1478 ; b) A. Kreimeyer, A. Perret, C. Lechaplais, D. Vallenet, C. Medigue, M. Salanoubat, J. Weissenbach, J. Biol. Chem. 2007, 282, $7191-7197$.

[8] a) A. Kahnert, M. A. Kertesz, J. Biol. Chem. 2000, 275, 31661-31667; b) J. Ogawa, T. Kodera, S. Smirnov, M. Hibi, N. Samsonova, R. Koyama, H. Yamanaka, J. Mano, T. Kawashima, K. Yokozeki, S. Shimizu, Appl. Microbiol. Biotechnol. 2011, 89, 1929-1938.

[9] J. A. Dale, H. S. Mosher, J. Am. Chem. Soc. 1973, 95, 512-519.

[10] M. Brandl, S. I. Kozhushkov, B. D. Zlatopolskiy, P. Alvermann, B. Geers, A. Zeeck, A. de Meijere, Eur. J. Org. Chem. 2005, 123-135.

[11] a) C. Jaime, R. M. Ortuno, J. Font, J. Org. Chem. 1986, 51, 3946-3951; b) I. Dinarés, A. Entrena, C. Jaime, C. Segura, J. Font, Electron. J. Theor. Chem. 1997, 2, 160-167; c) Y. Cai, C.-C. Ling, D. R. Bundle, Org. Biomol. Chem. 2006, 4, 1140-1146.

[12] J. Wityak, S. J. Gould, S. J. Hein, D. A. Keszler, J. Org. Chem. 1987, 52, 2179-2183.

[13] These new enzymatic reactions have been edited in the Rhea database (EMBL-European Bioinformatics Institute, http://www.ebi.ac.uk): 
L-lysine to (3S)-hydroxy-L-lysine, RHEA:40748; L-lysine to (4R)-L-lysine, RHEA:42421; and L-ornithine to (3S)-L-ornithine, RHEA:40932.

[14] C. Vergne-Vaxelaire, F. Bordier, A. Fossey, M. Besnard-Gonnet, A. Debard, A. Mariage, V. Pellouin, A. Perret, J.-L. Petit, M. Stam, M. Salanoubat, J. Weissenbach, V. De Berardinis, A. Zaparucha, Adv. Synth. Catal. 2013, $355,1763-1779$.

[15] S. Rozen, H. Skaletsky, Methods Mol. Biol. 2000, 132, 365-386.
[16] C. Aslanidis, P. J. de Jong, Nucleic Acids Res. 1990, 18, 6069-6074.

Received: June 30, 2014

Revised: July 17, 2014

Published online on September 11, 2014 